\title{
PENGARUH MODEL PEMBELAJARAN INQUIRY TRAINING TERHADAP KEMAMPUAN BERPIKIR KRITIS SISWA PADA MATERI POKOK FLUIDA STATIS DI KELAS XI SMA NEGERI 4 KISARAN T.P 2015/2016
}

\author{
Afrina Sari Br. Rambe dan Winsyahputra Ritonga \\ Jurusan Fisika FMIPA Universitas Negeri Medan \\ afrinasarirambe99@yahoo.com
}

\begin{abstract}
ABSTRAK
Penelitian ini bertujuan untuk mengetahui pengaruh model pembelajaran inquiry training terhadap kemampuan berpikir kritis siswa pada materi pokok Fluida Statis di Kelas XI SMA Negeri 4 Kisaran T.P 2015/2016. Jenis penelitian ini adalah quasi experiment. Populasi dalam penelitian ini seluruh siswa kelas XI semester genap SMA Negeri 4 Kisaran yang terdiri dari empat kelas. Sampel penelitian ditentukan dengan teknik cluster random sampling dan diberikan perlakuan yang berbeda yang masing-masing kelas berjumlah 33 orang, kelas XIIPA2 sebagai kelas eksperimen dengan model pembelajaran inquiry training dan XI-IPA3 sebagai kelas kontrol dengan pembelajaran konvensional. Instrumen yang digunakan adalah tes kemampuan berpikir kritis yakni tes uraian yang terdiri dari 10 item dan diperoleh hasil postes dengan hasil rata-rata kelas eksperimen 86,48 dan kelas kontrol 81,63. Hasil penelitian diperoleh 0,012<0,05. Ada pengaruh yang signifikan kemampuan berfikir kritis siswa menggunakan model pembelajaran pembelajaran inquiry training dari pembelajaran Konvensional pada materi pokok fluida statis di kelas XI SMA Negeri 4 Kisaran T.P. 2015/2016.
\end{abstract}

Kata Kunci: inquiry training, kemampuan berpikir kritis, fluida statis

\begin{abstract}
This study aims to determine the effect of inquiry learning model training on students' critical thinking skills in the subject matter Fluid Static in Class XI SMAN 4 T.P Kisaran 2015/2016. This research is a quasi experiment. The population in this study throughout the semester class XI student of SMAN 4 The Kisaran consists of four classes. The research sample was determined by random cluster sampling technique and given a different treatment that each class numbered 33 people, a class XI-IPA2 as a class experiment with inquiry learning model training and XI-IPA3 as the control class with conventional learning. The instrument used is the critical thinking skills test that test the description which consists of 10 items and post-test results obtained with an average yield of 86.48 experimental class and control class 81.63. The results were obtained $0.012<0.05$. There was a significant influence students' critical thinking skills using inquiry learning learning model of learning Conventional training in the subject matter of static fluid in class XI SMA Negeri 4 Kisaran T.P. 2015/2016.
\end{abstract}

Keywords: training inquiry, critical thinking skills, static fluid 


\section{PENDAHULUAN}

Proses pembelajaran fisika di Sekolah Menengah Atas (SMA) cenderung memposisikan ilmu fisika sebagai informasi yang harus disampaikan dan dihafalkan siswa. Guru merupakan pusat informasi yang bertugas menginformasikan rumus-rumus dan hukum-hukum fisika kepada para siswanya. Proses pembelajaran yang seharusnya lebih menekankan pada pentingnya belajar bermakna (meaningfull) dan keterlibatan siswa dalam proses pembelajaran tidak tercapai. Kebanyakan pelajaran fisika yang disampaikan guru berupa rumusrumus seringkali hanya dihafal siswa tanpa mengetahui makna dan tujuan rumus-rumus fisika tersebut, sehingga mempengaruhi hasil belajar siswa (Juliani dan Ginting, 2014).

Berdasarkan studi pendahuluan yang peneliti lakukan pada tanggal 23 Desember 2015 dengan cara menyebarkan menggunakan instrumen angket kepada 38 orang siswa di SMA Negeri 4 Kisaran kelas XI semester I diperoleh data sebagai berikut: $42 \%$ (16 siswa) menganggap bahwa pelajaran fisika biasa saja, 50\% (19 siswa) menyatakan suka dengan pelajaran fisika, 5,3\% (2 siswa) menyatakan tidak suka pelajaran fisika, dan $2,6 \%$ (1 siswa) menganggap tidak suka sekali pelajaran fisika. Berdasarkan angket juga diperoleh $39,5 \%$ (15 siswa) memilih mengerjakan soal dan diskusi kelompok, 39,5\% (15 siswa) memilih praktikum dan demostrasi, 13\% (5 siswa) memilih belajar dan bermain, dan $8 \%$ (3 siswa) memilih hanya mendengarkan penjelasan dari guru. Data diperoleh 68\% (26 siswa) menyatakan guru hanya mencatat dan mengerjakan soal dikelas, $24 \%$ (9 siswa) menyatakan guru hanya berdiskusi dan tanya jawab saat dikelas, 7,9\% (3 siswa) menyatakan guru berceramah saat pembelajaran dikelas. Siswa juga jarang menggunakan laboratorium hal ini terbukti dari data yakni 68\% (26 siswa) menyatakan tidak pernah menggunakan laboratorium saat pembelaran, $24 \% \quad(9$ siswa) menyatakan pernah menggunakan menggunakan laboratorium, 5,3\% (2 sisiwa) menyatakan sering menggunakan laboratoium, dan 2,6\% (1 siswa) menyatakan kadangkadang mengunakan laboratorium.

Peneliti juga melakukan wawancara dengan guru fisika di SMA Negeri 4 Kisaran, beliau mengemukakan bahwa hasil belajar fisika masih kurang memuaskan, hanya $50 \%$ siswa yang berhasil mendapatkan nilai di atas KKM. Terbukti dari nilai ulangan harian para siswa yang diperoleh dengan nilai rata-rata hanya mencapai 68 . Beliau juga mengatakan bahwa bila siswa diajarkan secara teori, maka minat siswa terhadap pelajaran fisika masih kurang, ditandai dengan adanya sebagian siswa bersemangat dan sebagian lainnya kurang bersemangat. Adanya keterbatasan penyediaan alat-alat laboratorium di sekolah membuat guru sulit untuk menciptakan pembelajaran yang menarik dan menyenangkan. Metode pembelajaran yang paling sering digunakan oleh guru adalah ceramah. 
Berdasarkan permasalahan di atas, maka untuk mengatasinya diperlukan suatu model dan metode pembelajaran yang dapat menarik minat siswa untuk mau mempelajari fisika dan membuat siswa paham mengenai konsep fisika. Model dan metode tersebut juga harus disesuaikan dengan tujuan pembelajaran dan materi pelajaran yang diajarkan.

$$
\text { Salah satu metode }
$$

pembelajaran yang mampu memfasilitasi agar siswa dapat memahami konsep fisika dengan metode eksperimen. Metode eksperimen ini siswa diberi kesempatan untuk mengalami sendiri atau melakukan sendiri, mengikuti proses, mengamati suatu objek, menganalisis, membuktikan dan menarik sendiri tentang suatu objek, keadaan atau proses sesuatu (Sagala, 2012).

Model pembelajaran yang juga dapat mengatasi permasalahan di atas adalah model pembelajaran inquiry training. Inquiry training merupakan suatu rangkaian kegiatan belajar yang melibatkan secara maksimal seluruh kemampuan siswa untuk mencari dan menyelidiki secara sistematis, kritis, logis, analitis, sehingga mereka dapat merumuskan sendiri penemuannya dengan penuh percaya diri.

Model pembelajaran inquiry training dirancang untuk mengajak siswa secara langsung ke dalam waktu yang relatif singkat. Hasil penelitian Schlenker, dalam Joice dan Weil (2009) menunjukkan bahwa latihan inquiry training dapat meningkatkan pemahaman sains, produktif dalam berpikir kreatif , dan siswa menjadi terampil dalam memperoleh dan menganalisis informasi (Trianto, 2011).

Penelitian ini telah dilakukan sebelumnya oleh Umami dan Jatmiko (2013) dengan judul penerapan model pembelajaran inkuiri dengan pendekatan SETS untuk meningkatkan keterampilan berpikir kritis siswa pada pokok bahasan Fluida Statis mendapat respon yang positif dari siswa untuk Meningkatkan Keterampilan Berpikir Kritis siswa Kelas XI SMA Negeri 1 Gedangan.

Berdasarkan masalah di atas, penulis berkeinginan melakukan penelitian untuk mengetahui kemampuan berpikir kritis siswa yang dapat ditingkatkan dengan menggunakan model pembelajaran inquiry training.

\section{METODE PENELITIAN}

Penelitian ini dilaksanakan di SMA Negeri 4 Kisaran semester genap Tahun Pelajaran 2015/2016. Populasi dalam penelitian ini adalah seluruh siswa kelas XI Ilmu Pengetahuan Alam (IPA) Tahun Pelajaran 2015/2016. Sampel dalam penelitian ini terdiri dari dua kelas yaitu kelas XI IPA-3 sebagai kelas kontrol, dan kelas XI IPA-2 sebagai kelas eksperimen yang masingmasing berjumlah 33 orang. Kelas eksperimen dan kelas kontrol diambil dengan teknik claster random sampling, yaitu teknik pengambilan sample dari populasi dilakukan secara acak.

Penelitian ini melibatkan dua kelas yaitu kelas eksperimen dan kelas kontrol yang diberi perlakuan berbeda. Model inquiry training di kelas eksperimen, sedangkan pada kelas kontrol menggunakan 
pembelajaran konvensional. Desain penelitian ini dapat dilihat pada tabel 1:

Tabel 1. Two Group Pretes - Posttes Design

\begin{tabular}{|l|l|l|l|}
\hline Kelas & pretes & Perlakuan & postes \\
\hline Eksperimen & $\mathrm{T}_{1}$ & $\mathrm{X}$ & $\mathrm{T}_{2}$ \\
\hline Kontrol & $\mathrm{T}_{1}$ & $\mathrm{X}$ & $\mathrm{T}_{2}$ \\
\hline
\end{tabular}

Keterangan:

$\mathrm{T}_{1}=$ tes kemampuan awal (pretes)

$\mathrm{T}_{2}=$ tes kemampuan akhir (postes)

$\mathrm{X}=$ perlakuan pada kelas eksperimen yaitu penerapan model inquiry training

$\mathrm{Y}=$ perlakuan pada kelas kontrol yaitu penerapan model pembelajaran konvensional

Peneliti memberikan pretes pada kelas eksperimen dan kelas kontrol. Instrumen yang digunakan pada penelitian adalah tes kemampuan berpikir kritis terdiri dari 10 soal essay. Tes kemampuan berpikir kritis terlebih dahulu distandarisasi dengan menggunakan uji validitas isi oleh dua orang dosen dan satu guru sesuai dengan pakar ahlinya. Setelah data pretes diperoleh, dilakukan analisis data dengan uji normalitas yaitu uji liliefors, uji homogenitas dan uji kesamaan varians. Setelah itu dilakukan pengujian hipotesis uji $\mathrm{t}$ dua pihak untuk mengetahui kemampuan awal siswa pada kedua kelompok sampel dalam hal ini kemampuan awal kedua sampel tersebut harus sama. Selanjutnya peneliti mengajarkan materi pelajaran dengan menggunakan model inquiry training pada kelas eksperimen dan pembelajaran konvensional pada kelas kontrol. Perbedaan hasil akhir dapat diketahui dengan dilakukan postes menggunakan uji anava 1 jalur untuk mengetahui pengaruh perlakuan model inquiry training terhadap kemampuan berpikir kritis siswa.

\section{HASIL DAN PEMBAHASAN Hasil Penelitian}

Data yang dideskripsikan pada penelitian ini meliputi data kemampuan berpikir kritis siswa belajar fisika pada materi fluida statis, yang diberikan perlakuan berbeda yaitu 1) model inquiry training, 2) pembelajaran dengan menggunakan pembelajaran konvensional. Hasil data pretes siswa kelas eksperimen dan kelas kontrol dapat ditunjukkan pada gambar 1:

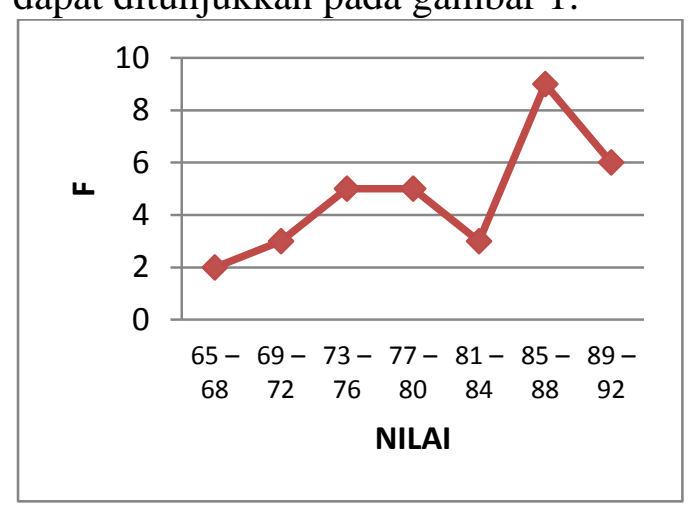

Gambar 1. Data pretes kelas eksperimen

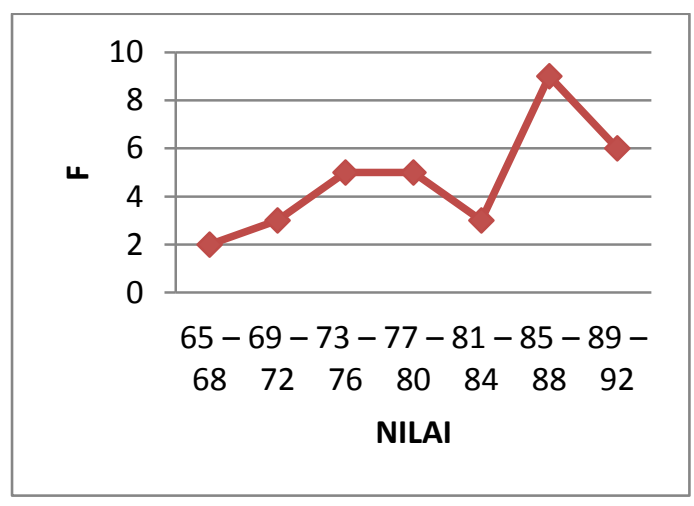

Gambar 2. Data pretes kelas kontrol

Gambar di atas menunjukkan bahwa nilai pretes pada kelas eksperimen dan kelas kontrol 
memiliki nilai yang rendah namun nilai kelas eksperimen dan kelas kontrol tidak jauh berbeda, perbandingan rata-rata nilainya adalah 51,48 dengan standar deviasi 10,73 dan 51,00 dengan standar deviasi 11,10.

Distribusi frekuensi data postes siswa kelas eksperimen dan kontrol dapat divisualisasikan pada gambar 3:

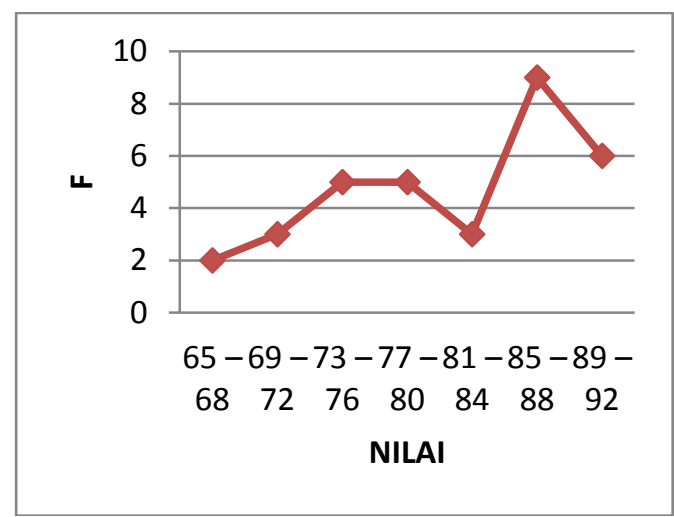

Gambar 3. Data postes kelas eksperimen

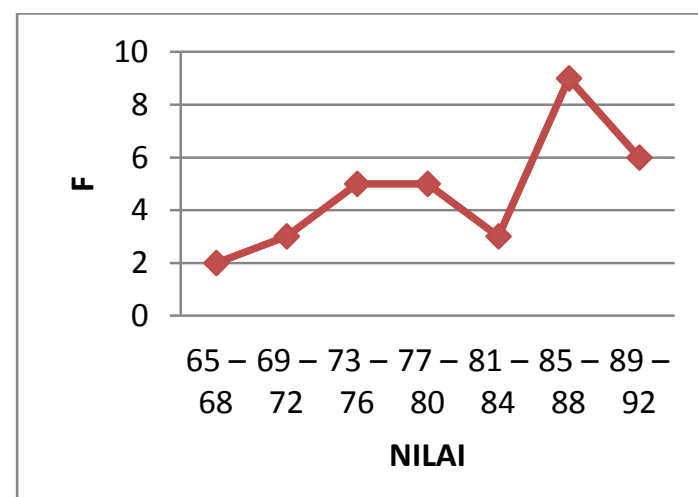

Gambar 4. Data postes kelas kontrol

Gambar 3 dan 4 di atas menunjukkan bahwa nilai postes kelas eksperimen lebih tinggi dari nilai postes kelas kontrol, perbandingan rata-rata nilainya adalah 86,48 dengan standar deviasi 7,22 dan 81,63 dengan standar deviasi 8,05 . Terdapat peningkatan kemampuan berpikir kritis siswa yang diperoleh pada kedua kelas, tetapi kelas eksperimen lebih baik dibandingkan dengan kelas kontrol.

Selain dari nilai pretes dan postes kemampuan berpikir kritis juga dapat dilihat dari penilaian lembar kerja siswa. Adapun nilai ratarata LKS setiap kelompok siswa selama melakukan 3 praktikum akan disajikan pada pada gambar dibawah ini:

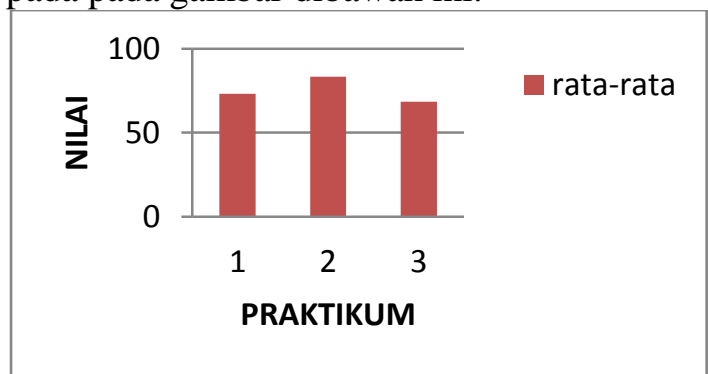

Gambar 5. Nilai Rata-rata Setiap Praktikum

\section{Pembahasan}

Nilai rata-rata pada pertemuan pertama yaitu 73,25 , pada pertemuan kedua terjadi peningkatan nilai ratarata yaitu 83,33 dan nilai rata-rata pada pertemuan ketiga yaitu 68,33.

Kemampuan berpikir kritis memiliki tahapan yang terbagi menjadi delapan sub indikator menurut Riyadi (2008) yakni: 1) menganalisis argumen, 2) bertanya dan menjawab pertanyaan, 3) memfokuskan pertanyaan. 4) mengobservasi dan mempertimbangkan laporan observasi, 5) mempertimbangkan kredibilitas (kriteria) suatu sumber, 6) membuat induksi dan mempertimbangkan induksi, 7) mengidentifikasi asumsi-asumsi 8) berinteraksi dengan orang lain untuk menentukan hasil tindakan.

Tahap pertama menganalisis argumen pada soal no 1 dengan penjelasan mengidentifikasi alasan (sebab) yang dinyatakan (eksplisit) kelas eksperimen diperoleh 100\% 
sama dengan perolehan presentase kelas kontrol yaitu 100\%. Tahap mengidentifikasi kerelevanan diperoleh persentase $100 \%$, sedangkan kelas konvensional $90 \%$. Tahap mencari persamaan dan perbedaan perolehan persentase $84 \%$, sedangkan kelas konvensional 75\%. Terakhir tahap merangkum perolehan persentase $18 \%$ dan kelas konvensional $0 \%$. Soal no 2 dengan indikator menganalisis argumen siswa yang diajarkan dengan model inquiry training dan konvensional mampu menjawab sampai tahap 3 dengan persentase $100 \%$ bedanya hanya pada tahap 4 yaitu merangkum kelas eksperimen perolehan persentase mencapai $84 \%$ dan pada kelas kontrol perolehan persentase $69 \%$.

Tahap kedua yaitu tahapan bertanya dan menjawab pertanyaan pada kelas eksperimen sama dengan kelas kontrol yakni sebesar $100 \%$.

Tahap ketiga memfokuskan pertanyaan kelas eksperimen dan kontrol dengan penjelasan mengidentifikasi atau merumuskan pertanyaan yaitu $100 \% \%$, tahap mengidentifikasi kriteria - kriteria untuk mempertimbangkan jawaban yang mungkin yaitu $100 \%$ kelas eksperimen dan kelas kontrol 93\%, menjaga kondisi pikiran yaitu $96 \%$ kelas eksperimen dan kelas kontrol 93\%. Tahapan memfokuskan pertanyaan, siswa masih belum menyelesaikan dengan benar, tidak lengkap dan beberapa siswa masih salah dalam melakukan perhitungan akhir.

Tahap keempat mengobservasi dan mempertimbangkan laporan observasi, kelas eksperimen dan kelas kontrol mendapatkan 100\% tahap dilaporkan oleh pengamat sendiri, tahap kemungkinan penguatan kelas eksperimen mendapatkan $100 \%$ dan kelas kontrol 93\%, tahap penguatan kelas eksperimen mendapatkan $90 \%$ dan kelas kontrol 63\%, dan tahap kondisi akses yang baik kelas eksperimen dan kontrol mendapatkan $0 \%$.

Tahap

kelima mempertimbangkan kredibilitas (kriteria) suatu sumber kelas eksperimen sama dengan kelas kontrol yakni sebesar $100 \%$.

Tahap keenam membuat induksi dan mempertimbangkan induksi kelas eksperimen sama dengan kelas kontrol yakni sebesar $100 \%$ pada tahapan kelompok yang logis, sedangkan pada tahap interprestasi kelas eksperimen sebanyak $87 \%$ dan kontrol $72 \%$ siswa.

Tahap ketujuh mengidentifikasi asumsi-asumsi terlihat bahwa kelas eksperimen hanya $36 \%$, sedangkan pada kelas kontrol $24 \%$.

Tahap kedelapan berinteraksi dengan orang lain untuk menentukan hasil tindakan terlihat bahwa kelas eksperimen sama dengan kelas kontrol yakni sebesar $100 \%$ pada tahapan merumuskan alternatif yang memungkinkan, sedangkan pada tahap mereview kelas eksperimen sebanyak $63 \%$ dan kontrol 69\% siswa.

Kemampuan berpikir kritis siswa di kelas eksprimen yang diajar dengan menggunakan model inquiry training diperoleh nilai rata-rata pretesnya 51,48 sedangkan nilai ratarata postes adalah 86,48. Peningkatan kemampuan bepikir kritis siswa di kelas eksperimen 
dikarenakan pada proses pembelajaran diberikan berbagai masalah yang berkaitan dalam kehidupan sehari-hari sesuai materi pembelajaran dan siswa dituntut untuk belajar secara aktif dan penuh semangat dalam proses berfikir secara kritis melalui pengetahuan awal dari pengalaman yang telah mereka alami sebelumnya dan menemukan sendiri informasi yang berkaitan dengan masalah.

Hal yang sama diungkapkan oleh Arisa (2014) dalam hasil penelitiannya yaitu model pembelajaran inquiry training adalah model pembelajaran yang proses pembelajarannya berawal dari rasa ingin tahu siswa terhadap sesuatu hal, kegiatan belajar yang melibatkan seluruh kemampuan siswa untuk mencari dan menyelidiki secara sistematis, kritis, logis, analitis, sehingga mereka dapat merumuskan sendiri penemuannya dengan penuh percaya diri.

Hal ini juga sesuai dengan teori yang mengatakan bahwa model pembelajaran inquiry training dirancang terutama untuk membantu siswa mengembangkan kemampuan berpikir, kemampuan menyelidiki permasalahan dan membuat siswa belajar membangun pengetahuan baru dan mengemukakan pendapatnya mengenai sesuatu setelah melalui proses berpikir kritis. (Joyce, dkk, 2011).

Kemampuan berpikir kritis siswa pada kelas kontrol yang diajar dengan menggunakan pembelajaran konvensional diperoleh nilai rata-rata pretesnya 51,00 sedangkan nilai ratarata postes adalah 81,63. Kemampuan berpikir kritis siswa kelas kontrol mengalami peningkatan tetapi nilai rata - rata kelas kontrol masih di bawah nilai rata - rata kelas eksperimen hal ini karena pada pembelajaran konvensional, siswa belajar lebih banyak mendengarkan penjelasan di depan kelas dan melaksanakan tugas jika diberikan latihan soal-soal kepada siswa. Pembelajaran konvensional pengajaran yang dilakukan dengan mengajar yaitu dengan menggunakan metode ceramah, tanya jawab.

Berdasarkan data pengujian uji anava 1 jalur diperoleh $\alpha_{\text {hitung }}<$ $\alpha_{\text {tabel }}$ yaitu $0,012<0,05$, hal ini menyatakan bahwa ada pengaruh model inquiry training terhadap kemampuan berpikir kritis siswa. Peningkatan kemampuan berpikir kritis siswa menggunakan model inquiry training dikarenakan inquiry training memiliki keunggulan daripada konvensional, pada saat proses pembelajaran dengan menggunakan model inquiry training siswa lebih banyak bekerja dan melakukan eksperimen sehingga siswa lebih mudah mengingat pelajaran dalam jangka panjang, sedangkan konvensional pembelajaran didominasi oleh guru dan siswa hanya sebagai pendengar pasif yang menyebabkan siswa sulit untuk mengingat pelajaran. Melalui data di atas dengan uji anava 1 jalur menunjukkan bahwa model inquiry training berpengaruh untuk meningkatkan kemampuan berpikir kritis siswa.

\section{KESIMPULAN DAN SARAN Kesimpulan}

Berdasarkan hasil penelitian yang diperoleh dari hasil analisa data dan pengujian hipotesis maka dapat disimpulkan sebagai berikut : 
1. Kemampuan berfikir kritis siswa yang diajarkan dengan model Pembelajaran Inquiry Training pada materi pokok Fluida Statis Kelas XI Semester II SMA Negeri 4 Kisaran T.P. 2015/2016 diperoleh nilai pretes dengan tingkat kategori "cukup" dan nilai postes dengan tingkat kategori "sangat baik".

2. Kemampuan berfikir kritis siswa yang diajarkan dengan pembelajaran Konvensional pada materi pokok Fluida Statis Kelas XI Semester II SMA Negeri 4 Kisaran T.P. 2015/2016 diperoleh nilai pretes dengan tingkat kategori "cukup" dan nilai postes dengan tingkat kategori "baik".

3. Berdasarkan hasil perhitungan uji anava 1 jalur, kemampuan berfikir kritis siswa pada kelas eksperimen lebih baik dari kemampuan berfikir kritis siswa kelas kontrol, berarti ada pengaruh model pembelajaran Inquiry Training terhadap kemampuan berfikir kritis siswa kelas XI semester II pada materi pokok fluida statis di SMA Negeri 4 Kisaran T.P. 2015/2016.

\section{SARAN}

1. Jika ingin meneliti dengan model pembelajaran yang sama dan juga menggunakan kemampuan berpikir kritis, ada baiknya bagi peneliti selanjutnya menginformasikan kepada siswa untuk mempelajari materi sebelum memulai pembelajaran dan bereksperimen.

2. Peneliti selanjutnya hendaknya pandai mengatur posisi duduk siswa dengan tepat sehingga pembelajaran dapat berjalan dengan kondusif dan lancar.
3. Peneliti selanjutnya hendaknya melakukan simulasi cara penggunaan alat laboratorium yang akan digunakan terlebih dahulu bersama siswa agar lebih menguasai semua dan mengatur waktu untuk melaksanakan sintaks tersebut dengan tepat waktu.

\section{DAFTAR PUSTAKA}

Arisa, Yeni., (2014), Pengaruh Model Pembelajaran Inquiry Training terhadap Hasil Belajar Siswa pada Materi Pokok Fluida Statis, Jurnal Inpafi Vol. 2, No. 4 hal: 54 - 60

Joyce, B., Weil, M., dan Calhoun, E., (2009), Models Of Teaching: (terjemahan) Model-Model Pengajaran Fisika edisi Kedelapan, Pustaka Pelajar, Yogyakarta

Juliani, R., dan Ginting, M.F., (2014), Pengaruh Model Pembelajaran Inquiry Training Terhadap Hasil Belajar Siswa Kelas X Sma Negeri 8 Medan T.P 2012/2013, Jurnal Inpafi Vol. 2 No. 1 hal: 122 - 131

\begin{tabular}{lrr} 
Riyadi, & \multicolumn{1}{c}{ U., (2008), } & Model \\
& Pembelajaran & Inkuiri \\
Dengan & Kegiatan \\
Laboraturium & Untuk \\
Meningkatkan & \\
Keterampilan & Berpikir \\
Kritis Siswa & pokok \\
Bahasan Fluida & Statis, \\
Tesis, Semarang &
\end{tabular}


Sagala, S., (2012), Konsep dan Makna Pembelajaran, Alfabeta, Bandung

Trianto, (2011), Mendesain Model Pembelajaran InovatifProgresif Konsep, Landasan, dan Implementasinya Pada Kurikulum Satuan Tingkat Pendidikan, Kencana, Jakarta

Umami, R., dan Jatmiko B, J., (2013), Penerapan Model Pembelajaran Inkuiri Dengan Pendekatan Sets (Science, Environment, Technology And Society) Pada Pokok Bahasan Fluida Statis Untuk Meningkatkan Keterampilan Berpikir Kritis Siswa Kelas XI SMA Negeri 1 Gedangan, Jurnal Inovasi Pendidikan Fisika Vol. 02 No. 03 hal: $61-69$ 